\title{
The Regulation of Courtesy: Does Kansas Need a Code of Professionalism?
}

\author{
Mike Hoeflich ${ }^{*} \&$ J. Nick Badgerow ${ }^{* *}$
}

\section{INTRODUCTION}

Over the past several decades, there has been a national discussion among lawyers and legal educators about the perceived decline in the professionalism of the bar. ${ }^{1}$ While some of this simply may be a product of nostalgia for a "golden age" of lawyer cooperation and civility, a review of ancient literature leads one to doubt when that "golden age" might have been. Many are the books and articles written by lawyers dating back at least as far as the nineteenth century decrying the lack of courtesy among lawyers. ${ }^{2}$ Indeed, Charles Dickens wrote a whole book about it. ${ }^{3}$ So, this recent "nostalgia" may be for a time that never existed.

- Kane Professor of Law, University of Kansas School of Law. The authors thank Tom Colonna, J.D. candidate 2013, University of Kansas School of Law, for his assistance on this Essay.

** Partner, Spencer Fane Britt \& Browne, LLP, Overland Park, Kansas; Member, Kansas Judicial Council; Chair, Kansas Judicial Council Civil Code Advisory Committee; Chair, Kansas Bar Association Ethics Advisory Committee; Member, Kansas Board of Discipline for Attorneys Chair, Johnson County (Kansas) Ethics \& Grievance Committee.

1. There is a vast amount of literature on professionalism and the lack thereof. For two particularly insightful examples, see Sol M. Linowitz, Regaining Respect for the Legal Profession: Some Suggestions, Keynote Address at Cornell Law School Centennial (April 15, 1988), in N.Y. ST B.J., Nov. 1988, at 8, and Committee on the Profession, Is Professionalism Declining?, 47 REC. ASS'N B. N.Y.C. 129 (1992).

2. See Hon. Warren E. Burger, Chief Justice, U.S. Supreme Court, The Necessity for Civility, Remarks at the Opening Session of the American Law Institute (May 18, 1971), in 52 F.R.D. 211, 213-14 (1971) (discussing the writing of a nineteenth-century barrister).

3. Charles Dickens, Bleak House (Norman Page ed., Penguin Books 1971) (1853). The author's condemnation of the bar is summarized in his thesis on attorney and client:

The one great principle of the English law is, to make business for itself. There is no other principle distinctly, certainly, and consistently maintained through all its narrow turnings. Viewed by this light it becomes a coherent scheme, and not the monstrous maze the laity are apt to think it. Let them but once clearly perceive that its grand principle is to make business for itself at their expense, and surely they will cease to grumble.

$I d$. at $603-04$. For an early example of public unhappiness with the law and the legal profession, see Honestus, Observations on the Pernicious Practice of the Law (Boston, True \& Weston 1819), reprinted in SOURCES OF THE HISTORY OF THE AMERICAN LAW OF LAWYERING 45 (Michael 
On the other hand, there is also reason to believe that twenty-firstcentury pressures on lawyers and law firms have, in fact, led to a more serious decline in the ways in which lawyers behave toward each other. At the present time, recent law graduates face a tough job market and heavy student debt. Law firms find themselves increasingly under pressure from clients to reduce costs and increase success rates. Outsourcing routine legal tasks to foreign, less expensive law firms or other service providers only increases the economic pressures on firms. Depression, gambling, and the use of alcohol and drugs by lawyers do not appear to be declining. ${ }^{4}$ It is not at all surprising, then, that in the face of so much economic, social, and professional pressure, some overstressed lawyers behave rudely and are less cooperative with their adversaries.

In 2009, in the face of these perceived problems, Robert E. Davis, the late Chief Justice of the Kansas Supreme Court, suggested that Timothy M. O'Brien, then-president of the Kansas Bar Association (KBA), form a commission on professionalism to explore ways in which to respond to this "crisis" at the bar." That commission has been working on these problems under O'Brien's leadership since its formation. The commission has met several times, and these writers were asked to be members of that commission. As a result, we have spent a good deal of time thinking about the matter of "professionalism" among Kansas lawyers, whether there is, in fact, a "crisis," and, if there is, what steps may be taken to best improve the situation.

It is our sense that there is a crisis, at least in two respects. First, there is no doubt that the general public neither understands nor appreciates the skill, dedication, and public service exhibited by the vast majority of Kansas lawyers. Most in the general public are frankly cynical about lawyers and the entire system of justice. Second, as many lawyers and judges have expressed, it seems that civility, decency, and cooperation among Kansas lawyers is on the decline, based on personal experience, case reports, and anecdotal evidence.

Having concluded that there is a crisis, however, we have also concluded that the solution to this crisis is not the adoption of a "code of professionalism"-in the sense of a system of regulatory rules

H. Hoeflich ed., 2007).

4. See J. Nick Badgerow, Apocalypse at Law: The Four Horsemen of the Modern Bar-Drugs, Alcohol, Gambling and Depression, 18 PROF. LAW., no. 3, 2007 at 2, 2.

5. Letter from Hon. Robert E. Davis, Chief Justice, Kan. Supreme Court, to Tim O'Brien, Esq., Clerk of the Court, U.S. Dist. Court for the Dist. of Kan. (Oct. 1, 2009) (on file with author). 
accompanied by sanctions for their violation-as has been done in several states. Instead, we suggest a combination of efforts that (a) use existing means of controlling inappropriate behavior, (b) adopt a new requirement for mandatory "professionalism" education for law students who wish to become members of the Kansas bar, and (c) require annual continuing education for lawyers once they become members of the bar. This last effort is already a requirement in Kansas. ${ }^{6}$

\section{WHAT IS "PrOFESSIONALISM"?}

One of the first problems in addressing the crisis in professionalism is to define the term "professionalism." Every lawyer and law student understands that the terms "legal ethics" or "professional responsibility" refer to the types of behavior addressed by the Kansas Rules of Professional Conduct $^{7}$ and enforced by the Kansas Disciplinary Administrator ${ }^{8}$ under the aegis of the Kansas Board for Discipline of Attorneys. ${ }^{9}$

But there is no such easy definition for "professionalism." Indeed, it is our experience that there is no precise definition of the term to which a majority of lawyers would agree. To a large degree, however, it appears that when lawyers speak of professionalism, most talk about behaviors covered by the old-fashioned term "professional deportment." we mean the minimum level of civility in word and action that lawyers believe every lawyer should show every other lawyer, the minimum level of cooperation expected among lawyers in adversarial and nonadversarial situations, and the minimum degree of courtesy one would expect lawyers to show each other. An example of minimum civility might be refraining from using insulting terms or shouting when speaking to another lawyer. An example of cooperation might be a willingness to schedule meetings, depositions, and trial dates at times that do not cause an undue burden to another lawyer. An example of minimum courtesy might be returning telephone calls in a reasonable

6. KAN. SUP. CT. R. 802.

7. KAN. SUP. CT. R. 226.

8. KAN. SUP. CT. R. 205.

9. KAN. SUP. CT. R. 204.

10. The use of this phrase in the American legal context dates back at least to the first half of the nineteenth century. See David HofFMan, Fifty Rules on Professional Deportment, in A Course of Legal Study, Addressed to Students and the Profession Generally 720 (Baltimore, Joseph Neal 1836), reprinted in SOURCES supra note 3, at 181. 
time and arriving at scheduled events on time. Most lawyers would agree with these examples - at least in theory-but, unfortunately, they do not always employ them in practice.

On August 23, 2011, the Kansas Bar Association Commission on Professionalism adopted the following general definition, as proposed by a subcommittee appointed for that purpose: “'Professionalism' focuses on actions. A professional lawyer acts with civility, respect, fairness, learning and integrity, towards clients, as an officer of the legal system, and as a public citizen with special responsibilities for the quality of justice." ${ }^{11}$ Using this definition, the profession can observe and judge a lawyer's actions, while not judging a lawyer's thoughts. The definition appreciates every lawyer's tripartite obligations: first, to clients, which provides the opportunity to serve and earn a livelihood; second, to the system of justice, which provides the arena for the lawyer's work; and third, to the public, which affords the lawyer her special franchise. ${ }^{12}$ Indeed, many professional considerations, as well as many ethical issues, arise from the tension between or among these forces that pull lawyerssometimes in differing directions.

Lawyers wish to be perceived by clients as zealous advocates, and indeed, the Model Rules require such zeal. ${ }^{13}$ On the other hand, lawyers wish to be accepted as able and knowledgeable by the tribunals before which they practice and should avoid burning bridges with courts or opposing counsel with whom they will presumably continue to work long after a single case concludes.

\section{Professionalism CODES}

One of the most popular responses to the professionalism crisis at the bar today has been to call for the formulation and adoption of so-called "professionalism codes." While there are differences among the various professionalism codes that have been adopted in the United States, all

11. Agenda and Materials from the Kan. B. Ass'n to the KBA Comm'n on Professionalism 4 (Aug. 23, 2011) (on file with author).

12. See generally Robert Audi, The Ethics of Advocacy, 1 LEGAL THEORY 251 (1995) (discussing in detail the tripartite obligations to client, court, and public).

13. KAN. Rules of Prof'L CONDUCt R. 1.3 (2007), in KAN. SUP. CT. R. 226 ("A lawyer shall act with reasonable diligence and promptness in representing a client."). The Comments then explain that "[a] lawyer should act with commitment and dedication to the interests of the client and with zeal in advocacy upon the client's behalf." Id. at R. $1.3 \mathrm{cmt}$. 1. See also In re Vanderbilt, 110 P.3d 419, 422 (Kan. 2005) (per curiam) (finding that attorney violated Kansas Rule 1.3 by failing to act with sufficient diligence in representing his client). 
strive to mandate and regulate the types of behavior outlined above. ${ }^{14}$ An example of the intent behind these codes is illustrated by the preamble to the Virginia State Bar's Principles of Professionalism:

Virginia can take special pride in the important role its lawyers have played in American history. From Thomas Jefferson to Oliver Hill, Virginia lawyers have epitomized our profession's highest ideals. Without losing sight of what lawyers do for their clients and for the public, lawyers should also focus on how they perform their duties. In their very first professional act, all Virginia lawyers pledge to demean themselves "professionally and courteously." Lawyers help their clients, the institutions with which they deal and themselves when they treat everyone with respect and courtesy. These Principles of Professionalism serve as a reminder of how Virginia lawyers have acted in the past and should act in the future. ${ }^{15}$

While not formally adopted by the Kansas Supreme Court, the KBA published eleven principles of professionalism under the name Hallmarks of Professionalism. ${ }^{16}$ Under these principles, adherents agree that a lawyer:

1. Shows respect for the legal system through appearance, manner, and conduct at all times;

2. Does not discuss client's affairs socially;

3. Does not blame others for the outcome of a case;

4. Recognizes one's income is secondary to serving the best interest of the client;

5. Communicates with clients, other lawyers, and the judiciary in a timely and complete manner and is prompt for all appointments;

6. Does not engage in ex parte communication with the court;

14. See generally Allen K. Harris, The Professionalism Crisis-The ' $z$ ' Words and Other Rambo Tactics: The Conference of Chief Justices' Solution (pts. 1 \& 2), 12 Prof. LAW., Winter 2001, at 1, 12 PROF. LAW., Spring 2001, at 1; Joan C. Rogers, Special Report, Disruptive Courtroom Behavior Usually Can't be Defended as Zealous Advocacy, 27 LAW. MANUAL ON PROF. CONDUCT (ABA/BNA) 580 (2011) (discussing different civility measures around the country).

15. VA. St. B., PRINCIPLES OF PROFESSIONALISM (2009), available at http://www.vsb.org/proguidelines/index.php/principles/.

16. KAN. B. ASS'N, Hallmarks OF PROFEsSionalism, http://www.ksbar.org/public/ hallmarks.shtml (last visited Sept. 15, 2011). 
7. Expedites the resolution of disputes through research, articulation of claims, and clarifying the issues;

8. Abides by commitments regardless of whether they can be enforced in a courtroom;

9. Who as a member of the judiciary should avoid speech and gestures that indicate opinions not germane to the case, require lawyers to be comprehensible in the courtroom, and discuss pending cases only when all parties are present;

10. Is always mindful of the responsibility to foster respect for the role of the lawyer in society; and

11. Demonstrates respect for all persons, regardless of gender, race, or creed. $^{17}$

Similar aspirational codes have been adopted by a number of local bar associations around the country, including the Johnson County (Kansas) Bar Association in 1989. ${ }^{18}$ This Creed ${ }^{19}$ - and, indeed, many others-begins with a Preamble, which states a lawyer's overall commitment to conduct herself in such a way that extends "civility and courtesy ... to [her] clients, to [her] fellow attorneys, and to the courts and tribunals in which [she] practice[s]."20

The Creed then follows the Preamble with four rules relating respectively to a lawyer's dealings with clients, with opposing parties and their attorneys, with courts, and with the public and our system of justice. $^{21}$ Each rule includes specific tenets, which explain in more detail

17. Id.

18. AM. B. ASS'N, PROFESSIONALISM CODES, http://www.americanbar.org/groups/ professional_responsibility/resources/professionalism/professionalism_codes.html (last visited Sept. $15,2011)$. In Kansas, Johnson County calls its code the "Creed of Professional Conduct." JOHNSON CNTY. B. ASS'N, CREED of ProfessionAl CONDUCT (1989), available at http:/www.jocobar.org/ displaycommon.cfm?an=1\&subarticlenbr=1.

19. JOHNSON CNTY. B. Ass'N, supra note 18. A more thorough and preferable-at least to these authors-Lawyer's Creed of Professionalism is set forth in the Appendix to this Essay. See infra Part VI. For a fuller description and exegesis on the Creed, see J. Nick Badgerow, The Lawyers' Creed of Professionalism: Some Observations from the Field, 69 J. KAN. B. Ass'N 24 (2000).

20. JOHNSON CNTY. B. ASs'N, supra note 18 (emphasis added). The Kansas Rules of Professional Conduct also recognize these three duties. "A lawyer, as a member of the legal profession, is a representative of clients, an officer of the legal system and a public citizen having special responsibility for the quality of justice." KAN. SUP. CT. R. 226 pmbl. [16], in KAN. SUP. CT. R. 226.

21. JOHNSON CNTY. B. ASS'N, supra note 18. 
the duties and obligations of a professional to the client, other attorneys, the courts, and the legal system. ${ }^{22}$

Although aspirational statements such as these may well influence certain lawyers and reassure the public that the legal profession is concerned with issues of professionalism, it seems obvious that they have not served to stop or, perhaps, even slow the perceived decline in professional behavior among lawyers. On the other hand, the mandatory behavioral rules set out in the Model Rules of Professional Conduct as adopted by the various states have also not been totally effective in this regard. To a large extent, this is so because the Model Rules primarily concern the ways in which lawyers interact with their clients, the courts, and the general public. ${ }^{23}$ Few rules relate to issues of civility, courtesy, and cooperation among lawyers. ${ }^{24}$ Indeed, it is fair to say that the absence of such topics in the Model Rules is attributable to the belief of the lawyers and judges who formulated them that there was no need to address these topics because they assumed that lawyers would behave in such ways towards each other. ${ }^{25}$ The problem today, of course, is that such assumptions seem to be false.

Additionally, the Model Rules prescribe minimum standards for conduct, the violation of which will, and should, often lead to discipline. ${ }^{26}$ On the other hand, professionalism should make a lawyer feel compelled to do more than the minimum required just to avoid being disciplined. ${ }^{27}$

One may argue that if aspirational statements about professionalism - such as the Hallmarks or the Creed - are not effective and if the current regulatory scheme for controlling lawyer behavior, like the Model Rules, does not reach such matters, then the answer to the "crisis" now facing the bar is to expand the Model Rules or create a new

22. Id.

23. See MODEl RULES OF PROF'L CONDUCT pmbl. (1983) (describing the main focus of the Model Rules).

24. See Model Rules of Prof'L Conduct R. 3.3-3.5 (1983).

25. One may trace the Model Rules back to the first rules of professional conduct published by the American Bar Association in 1908, which themselves derive, in large part, from the code adopted by the Alabama bar in 1898. See generally SOURCES, supra note 3 (outlining the history and development of the modem Model Rules).

26. MODEL RULES OF PROF'L CONDUCT pmbl. (1983).

27. See Kan. Rules of Prof'l Conduct pmbl. [16], in Kan. Sup. CT. R. 226 ("The Rules do not, however, exhaust the moral and ethical considerations that should inform a lawyer, for no worthwhile human activity can be completely defined by legal rules. The Rules simply provide a framework for the ethical practice of law."). 
regulatory scheme to control professionalism among lawyers. We disagree with this argument on at least two principal grounds. ${ }^{28}$

The first ground for rejecting a regulatory scheme for ensuring professionalism at the bar is pragmatic. If the state adopted a new set of professionalism rules, the heavy case load borne by the Disciplinary Administrator's Office would, in all likelihood, increase substantially, perhaps even double. Such an increase would require new resources and staff, and it might well weaken the investigation and prosecution of complaints filed under the existing Kansas Rules. ${ }^{29}$ Since these existing rules go to the very heart of the legal profession-that is, lawyer-client relations-any weakening of the enforcement effort would be undesirable.

The second ground for rejecting the adoption of new specific regulatory rules on professionalism looks to the danger of subjective judgments in the prosecution and enforcement of such rules. Notions of courtesy, civility, and cooperation are not fixed or precise. What is a reasonable time in which to return a telephone call to one individual in a particular circumstance may be highly unreasonable to another. Circumstances will frequently play a large role in determining reasonableness in such a case. What is proper professional attire is a question to which different individuals and forums may have very different answers. Attempts at specific regulatory rules may well lead to an overwhelming number of complaints (many of them groundless), cross-complaints, and endless wrangling - all to the expense of clients in the forms of fees and delay. Further, if the regulatory code requires investigation, prosecution, and potential sanction for these issues, then we predict that the process would be an administrative nightmare. It will also be extremely difficult to arrive at a uniform application of such rules. Therefore, it would be far better to establish aspirational rules with a degree of generality and then leave it to judges to use their inherent powers to ensure compliance.

28. At the August 23, 2011 meeting of the KBA Commission on Professionalism, as attended by the authors, Vice-Chairman Judge Robert J. Fleming indicated that the Kansas Supreme Court does not presently favor a regulatory-type code of professionalism.

29. See KAN. SUP. CT. R. 201-226 (outlining the standards by which attorneys should conduct themselves and the rules relating to the discipline of attomeys). 


\section{Alternative SOlutions to The Professionalism CRISIS}

We suggest two means by which to deal with the current professionalism crisis. First, the State should require law school and post-graduate continuing education. Second, the State should increase the use of existing regulatory mechanisms.

\section{A. Education}

The current approach to maintaining the ethics of the practicing bar is twofold. First, lawyers are subject to professional discipline according to rules adopted by the supreme court in every state. The Kansas Supreme Court requires that every lawyer comply with the Kansas Rules, ${ }^{30}$ which are enforced by the Kansas Disciplinary Administrator. ${ }^{31}$ This office investigates and prosecutes complaints against lawyers for breaches of the Kansas Rules and convenes hearing panels to adjudicate those complaints deemed sufficiently serious to warrant such a process. ${ }^{32}$ The Kansas Supreme Court is also authorized to hear complaints, ${ }^{33}$ and it does so de novo and on the record. ${ }^{34}$ This is the regulatory part of the professional responsibility process.

The second part of the process is educational. Every law school accredited by the American Bar Association is required to provide professional responsibility training to law students. ${ }^{35}$ Interpretation $302-$ 9 of ABA Standard 302(a)(5) of the ABA Standards for the Approval of Law Schools, applicable to all accredited law schools, states: "The substantial instruction in the history, structure, values, rules, and responsibilities of the legal profession and its members required by Standard 302(a)(5) includes instruction in matters such as the law of lawyering and the Model Rules of Professional Conduct of the American Bar Association."36

30. See Kan. SUP. CT. R. 201-202.

31. KaN. SUP. CT. R. 205.

32. Id.

33. See KAN. SUP. CT. R. 212.

34. See State v. Dixon, 664 P.2d 286, 290 (Kan. 1983) (per curiam) (citing KAN. SUP. CT. R. 212(f)) (noting that recommendations from disciplinary panels are not binding on the court).

35. AM. B. ASS'N, ABA STANDARDS FOR APPROVAL OF LAW SCHOOLS 2011-2012, Standard 302, http://www.americanbar.org/content/dam/aba/publications/misc/legal_education/Standards/ 2011_2012_aba_standards_chapter3.authcheckdam.pdf.

36. Id. 
In addition to the instruction requirement imposed on schools by the $\mathrm{ABA}$, Kansas requires that every applicant to the bar achieve a passing grade on the Multistate Professional Responsibility Examination (MPRE) as a condition of bar admission. ${ }^{37}$ Furthermore, once admitted, all actively licensed members of the Kansas bar must complete two hours of continuing education in professional responsibility annually to remain in good standing. ${ }^{38}$ This is the educational portion of the professional responsibility scheme adopted in Kansas and most other states.

We propose establishing a similar educational structure to ensure that law students and lawyers become thoroughly familiar with principles of legal professionalism not currently covered by professional responsibility courses in law schools, the MPRE, or continuing education programs. The simplest way to achieve this in the State would be for the Kansas Supreme Court to adopt a rule that all applicants to the Kansas bar must have undergone instruction in professionalism topics as part of their law school education. At a minimum, we suggest that the State require completion of a one-credit-hour course in professionalism. This could be added to existing courses in professional responsibility, many of which are two-credit-hour courses. The supreme court could establish a small committee of Kansas practitioners, judges, and law teachers to develop a model curriculum for such a course. Second, either the MPRE or the essay portion of the Kansas bar examination should test principles of legal professionalism. Finally, the current two-hour ethics continuing education requirement should be expanded to three hours, one hour of which would focus on legal professionalism.

All of these changes would be relatively simple and inexpensive to implement. The adoption of these educational requirements would not only ensure that every law student and member of the bar had knowledge of the basic principles of legal professionalism, but would also make it clear that the legal profession places a high value on such principles.

\section{B. Existing Mechanisms to Enforce Professionalism}

Whenever there are discussions of declining standards of professionalism in the Kansas bar, someone suggests that existing rules and laws do not, and will not, provide effective methods of regulating unprofessional behavior unless it is clearly proscribed by the Kansas

37. KAN. SUP. CT. R. 709(n).

38. KAN. SUP. CT. R. 802(a). 
Rules. We believe that this is untrue. In fact, judges-particularly in their power to hold attorneys in contempt - have substantial ability to stop and even punish unprofessional behavior by lawyers, irrespective of the Kansas Rules. Further, an expansive view of several of the provisions contained in the Kansas Rules would permit their use in regulating unprofessional behavior.

\section{Judicial Power}

Judges have substantial power to regulate lawyers through their ability to deny motions, apply sanctions through their orders of contempt, ${ }^{39}$ and, in the case of lawyers from outside the jurisdiction, deny or revoke petitions to be admitted pro hac vice. ${ }^{40}$ While judges should not overuse these powers, they may employ them to maintain appropriate standards of professionalism among the bar. A few examples will demonstrate this.

Perhaps a favorite example of the appropriate use of judicial power to maintain standards of civility at the bar is the recent order by Judge Melgren in Jayhawk Capital Management, LLC v. LSB Industries, Inc. ${ }^{41}$ One of the lawyers asked for a brief continuance in the litigation so that he could travel home to Dallas to be with his wife when she gave birth to their first child. $^{42}$ Opposing counsel refused to agree to the continuance. ${ }^{43}$ Judge Melgren, astonished at what he perceived to be the utter callousness of opposing counsel in the matter, took the opportunity to address the issue of civility at the bar.

Regrettably, many attorneys lose sight of their role as professionals, and personalize the dispute; converting the parties' disagreement into a lawyers' spat. This is unfortunate, and unprofessional, but sadly not uncommon. Before the Court, however, is an uncommon example of this unhappy trend.

39. See KAN. STAT. ANN. $\S \S 20-1201$ to -1206 (2007) (outlining types of contempt and procedure for finding it). See generally Rogers, supra note 14 (giving a national view of the use of judicial powers and existing regulations to control bad conduct by lawyers).

40. See KAN. SUP. CT. R. 116 (explaining the process of admitting an out-of-state attorney).

41. Order on Motion to Continue, Jayhawk Capital Mgmt., LLC v. LSB Indus., Inc., No. 082561-EFM (D. Kan. Apr. 12, 2011), ECF No. 163.

42. Id. at $1-2$.

43. Id. at 2 . 
[T]his judge is convinced of the importance of federal court, but he has always tried not to confuse what he does with who he is, nor to distort the priorities of his day job with his life's role. Counsel are encouraged to order their priorities similarly. ${ }^{44}$

Judge Melgren then granted the motion for a continuance, congratulated the young lawyer and his wife, and sent him home to witness the blessed event. $^{45}$ Not surprisingly, Judge Melgren's decision in this matter was lauded widely and even merited positive mention in the New York Times. ${ }^{46}$ Simply by exercising good judgment in his decision, Judge Melgren struck a blow for civility at the bar.

The District Court for the Northern District of Texas took an even stronger position in Dondi Properties Corp. v. Commerce Savings \& Loan Ass' $n .^{47}$ In this 1988 case, the court adopted the Dallas Bar Association's Guidelines of Professional Courtesy and Lawyer's Creed as a standard of practice for itself. ${ }^{48}$ The court accompanied this adoption with a strong statement of its views on incivility at the bar:

Attorneys who abide faithfully by the standards we adopt should have little difficulty conducting themselves as members of a learned profession whose unswerving duty is to the public they serve and to the system of justice in which they practice. Those litigators who persist in viewing themselves solely as combatants, or who perceive that they are retained to win at all costs without regard to fundamental principles of justice, will find that their conduct does not square with the practices we expect of them. Malfeasant counsel can expect instead that their conduct will prompt an appropriate response from the court, including the range of sanctions the Fifth Circuit suggests in the Rule 11 context: "a warm friendly discussion on the record, a hard-nosed reprimand in open court, compulsory legal education, monetary sanctions, or other measures appropriate to the circumstances."

... We do intend ... to take the steps necessary to ensure that justice is not removed from the reach of litigants either because improper litigation tactics interpose unnecessary delay or because such actions increase the cost of litigation beyond the litigant's financial grasp. ${ }^{49}$

44. Id. at 1,3 .

45. Id. at 3 .

46. John Schwartz, Judge Rules for Counsel, Saying Baby Comes First, N.Y. TIMES, Apr. 14, 2011 , at A15.

47. 121 F.R.D. 284 (N.D. Tex. 1988) (en banc) (per curiam).

48. Id. at 287 .

49. Id. at 288 (citation omitted) (quoting Thomas v. Capital Sec. Servs., Inc., 836 F.2d 866, 878 (5th Cir. 1988) (en banc)). 
The threat of financial sanctions for unprofessional conduct made in Dondi was realized in the District Court for the Southern District of Florida in Judge Middlebrooks' decision in the 2000 case of Lee $v$. American Eagle Airlines, Inc. ${ }^{50}$ In Lee, the lawyers representing the plaintiff utilized highly disruptive tactics during the trial, including what the judge characterized as "lash[ing] out" at him, "tossing a pen," "rolling [their] eyes," making "exasperated looks at the ceiling," "flailing of arms," and "exclaiming "This is outrageous.", 51 Throughout the trial, Judge Middlebrooks cautioned the lawyers to modify their behavior, but they failed to do so. ${ }^{52}$ Judge Middlebrooks' response to what he perceived as highly unprofessional behavior in his courtroom was ingenious. He did not penalize the plaintiff for his counsels' behavior. Instead, when it came time to award attorneys' fees to the plaintiff's lawyers, Judge Middlebrooks reduced that award "based upon misconduct of counsel" by $\$ 358,423.20 .^{53}$ He also transmitted a copy of his order to the Florida bar's disciplinary authorities. ${ }^{54}$ Judge Middlebrooks' message to the Florida bar was clear and unambiguous: behave appropriately or face a heavy financial penalty.

Judge Middlebrooks' sense of outrage expressed in Lee is echoed in an addendum to a 1994 opinion of the Supreme Court of Delaware in Paramount Communications, Inc. v. QVC Network, Inc. authored by Chief Justice Veasey. ${ }^{55}$ The court in this case was confronted by behavior in deposition practice that it considered inappropriate ${ }^{56}$ The subject of the court's ire was a prominent Texas litigator, Joe Jamail. ${ }^{57}$ The court, interestingly, raised the issue of Mr. Jamail's behavior sua sponte and did so because, in Judge Veasey's words, "[t]he issue of discovery abuse, including lack of civility and professional misconduct during depositions, is a matter of considerable concern to Delaware courts and courts around the nation." 58 The court was specifically concerned with an incident involving Mr. Jamail, which it characterized as demonstrating "such an astonishing lack of professionalism and

\footnotetext{
50. 93 F. Supp. 2d 1322, 1330-31 (S.D. Fla. 2000).

51. Id. at 1327.

52. Id. at $1325-29$.

53. Id. at 1336.

54. Id.

55. 637 A.2d 34, 51-57 (Del. 1994).

56. Id. at 52 .

57. Id. at $52-53$.

58. Id. at $52 \&$ n. 23 .
} 
civility that it is worthy of special note here as a lesson for the future-a lesson of conduct not to be tolerated or repeated."

The Addendum reprints a portion of the transcript of a deposition in which Mr. Jamail was present as counsel for the deponent although he "did not otherwise appear" in the litigation nor had he been admitted to practice pro hac vice. ${ }^{60}$ Without question, some of Mr. Jamail's comments pushed the limits of civility. For example, after telling his client not to answer a question, Mr. Jamail responded to pleas from opposing counsel with "Don't 'Joe' me, asshole. You can ask some questions, but get off of that. I'm tired of you. You could gag a maggot off a meat wagon." ${ }^{\circ 1}$ The Delaware Supreme Court expressed doubt about its disciplinary authority over Mr. Jamail because he was neither a member of the Delaware bar nor admitted to practice pro hac vice. ${ }^{62}$ Further, none of the parties had complained of Mr. Jamail's actions. ${ }^{63}$ The court, however, refused to let his actions go unnoticed.

[T] he Court finds this unprofessional behavior to be outrageous and unacceptable. If a Delaware lawyer had engaged in the kind of misconduct committed by Mr. Jamail on this record, that lawyer would have been subject to censure or more serious sanctions.... Under some circumstances, the use of the trial court's inherent summary contempt powers may be appropriate. ${ }^{64}$

Having recognized the uncertainty as to whether the Delaware Supreme Court had the power to sanction Mr. Jamail for his actions, the court did feel empowered to look to any future activities by Mr. Jamail in Delaware or involving cases before the Delaware courts, stating:

[C]onsideration will be given to the following issue[] for the future[:] ... whether or not it is appropriate and fair to take into account the behavior of Mr. Jamail in this case in the event application is made by him in the future to appear pro hac vice in any Delaware proceeding. ${ }^{65}$

It seems clear that this was not an idle threat by the court.

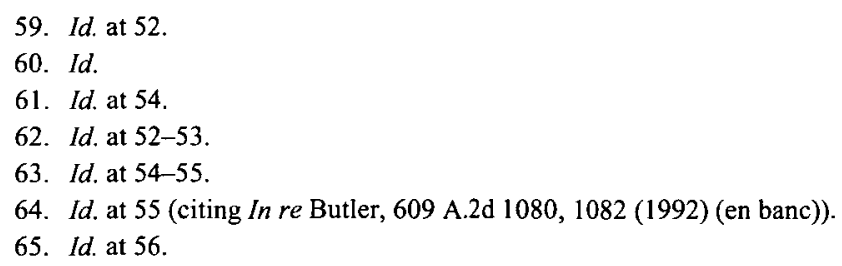


In all of the cases cited above, courts fashioned creative sanctions to impose on lawyers for their unprofessional conduct when such conduct was not, for some reason, directly subject to the jurisdiction's adopted rules of professional conduct. These decisions illustrate how a judge who is willing to exercise his inherent authority can, in fact, sanction uncivil and unprofessional conduct. Additionally, the decisions can be used as models for a judicial, non-regulatory mechanism to reduce such inappropriate behavior.

\section{Expanded Use of the Rules of Professional Conduct}

Although many lawyers and legal scholars probably believe that the rules of professional conduct, including the Kansas Rules, do not provide a means to control unprofessional behavior at the bar, an expansive view of several provisions may contradict this. The primary focus of the rules of professional conduct is not on lawyer-lawyer relations and behavior. There are, however, several provisions that touch upon this and that have been used to discipline lawyers who have acted unprofessionally.

For instance, in Kansas, Rule 3.5(d) requires that a lawyer refrain from "engag[ing] in undignified or discourteous conduct degrading to a tribunal,"66 and Rule 4.4 requires that a lawyer "[r]espect [the] [r]ights of [t]hird [p]ersons." ${ }^{, 67}$ Rule 8.4(c) prohibits a lawyer from "engag[ing] in conduct involving dishonesty, fraud, deceit or misrepresentation," Rule 8.4(d) prohibits a lawyer from "engag[ing] in conduct that is prejudicial to the administration of justice." ${ }^{\circ 9}$ These provisions have potentially broad scope and may control lawyer behavior not otherwise regulated by the other provisions of the Kansas Rules. These rules may certainly be used to control grossly unprofessional behavior by lawyers in a court or in a legal proceeding supervised by a court.

An example of such a use is In re Estiverne, a 1999 decision of the Louisiana Supreme Court. ${ }^{70}$ The lawyer's behavior in Estiverne was outrageous, if not bizarre. At a deposition in an opposing lawyer's office, Mr. Estiverne asked his opponent to "'step outside' and settle the matter 'man to man.", 71 He then left and, a bit later, returned with a

66. Kan. Rules of Prof'L Conduct R. 3.5(d) (2007), in Kan. SuP. CT. R. 226.

67. Id. at R. 4.4.

68. Id. at R. $8.4(\mathrm{c})$.

69. Id. at R. $8.4(\mathrm{~d})$.

70. 741 So. $2 \mathrm{~d} 649$ (La. 1999) (per curiam).

71. Id. at 650 . 
gun. ${ }^{72}$ Not surprisingly, the Supreme Court of Louisiana held such behavior to be a violation of Rules 4.4 and 8.4 of the Louisiana Rules of Professional Conduct. ${ }^{73}$

The Supreme Court of South Carolina also found its version of Rules 4.4 and 8.4 useful in addressing unprofessional behavior by a lawyer in a deposition in In re Golden, a 1998 decision. ${ }^{74}$ The respondent in this case had engaged in quite offensive behavior in several depositions. Among the more outrageous of these comments was that the deponent was "a mean-spirited, vicious witch" and that "[w]hat we need for her is a big bag to put her in without the mouth cut out." ${ }^{, 5}$ The court found that the use of such language clearly violated Rules 4.4 and 8.4 and imposed a public reprimand on the respondent attorney. ${ }^{76}$

The same two rules have been used with similar effect in Kansas. For example, in one case, the respondent made repeated allegations of misconduct on the part of court personnel, including the claim that he had been denied access to court records. "Th "Throughout his representation in the Baby $\mathrm{C}$ case, Respondent filed numerous pleadings containing serious allegations of misconduct by opposing counsel, members of the judiciary, Shawnee County District Court employees, and Kansas Court of Appeals staff." 78

In a separate matter also examined by the court, the respondent "became loud and angry" at court personnel. ${ }^{79}$ The Court identified one memorandum in which the respondent purported to

establish "a pattern and practice indicative of training and management of Kansas Judicial Branch employees that emphasizes enforcing interests of an administrative or bureaucratic nature at the expense of injuring fundamental Due Process rights of Kansas citizens who are guaranteed a republican form of government." He further accused judicial branch employees of "demoralizing" him and his client by "consistently obstructing this appeal."

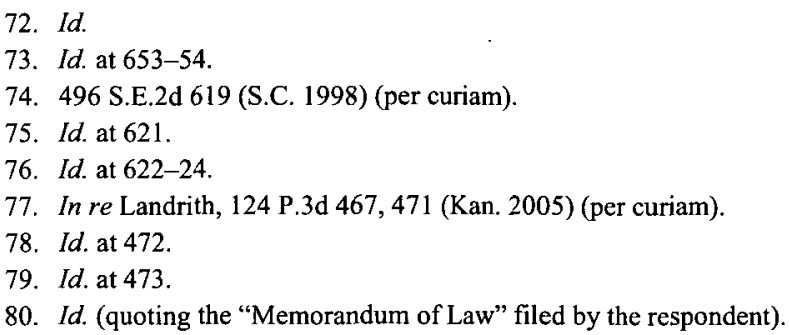


In his "Motion for Voluntary Withdraw [sic] and Disclosure of Costs," the respondent further stated "that judicial branch employees continually obstructed justice; that Carol Green, Clerk of the Appellate Courts, justified denial of access to the public record; that [his client's] due process rights were violated 'in this appeal by the agencies of the State of Kansas-Judicial Branch and the City of Topeka." ${ }^{\prime 81}$ In disbarring the respondent for the foregoing acts, as well as a litany of other actions, the Kansas Supreme Court affirmed the hearing panel's findings that this conduct violated Kansas Rules 4.4 and 8.4. ${ }^{82}$

In In re Black, the Kansas Supreme Court ordered an indefinite suspension of an attorney for his unprofessional conduct. ${ }^{83}$ Findings included a violation of Kansas Rule 4.4 based on the lawyer's "outburst" towards an opposing party, which included the following:

[Respondent], in anger, told [opposing counsel] he should not be wearing his uniform, that [opposing counsel] was a disgrace to the Kansas Army National Guard and to the United States Army, and that [respondent], if he had on his uniform, would have an eagle on his shoulders and he could put [opposing counsel] at attention such that [opposing counsel] could not speak. ${ }^{84}$

In yet another Kansas case, the respondent sent a letter to opposing counsel, which the court characterized as "vicious, offensive, and extremely unprofessional." ${ }^{85}$ Moreover, the "letter employed a number of vile and unprintable epithets." ${ }^{86}$ In affirming a finding that this conduct violated Kansas Rule 8.4(g)—which governs conduct reflecting adversely on the lawyer's ability to practice law-the Kansas Supreme Court set forth a thoughtful explanation of how the Kansas Rules can and should regulate and punish unprofessional conduct.

Suffice it to say that the correspondence to [opposing counsel] is conduct that adversely reflects on [respondent's] fitness to practice law. A lawyer should be able to write a letter to an opposing party or a party with an adverse interest and intelligently communicate his or her position without the use of profane, offensive, or derogatory language. "[A]ttorneys are required to act with common courtesy and civility at

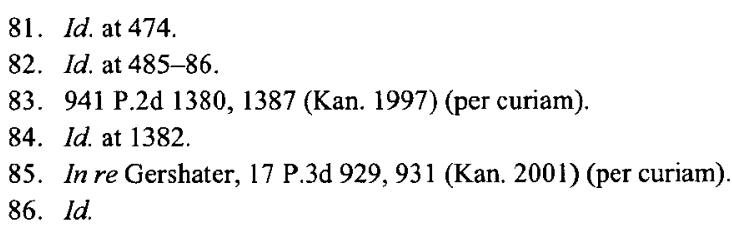


all times in their dealings with those concerned with the legal process." "Vilification, intimidation, abuse and threats have no place in the legal arsenal." "An attorney who exhibits the lack of civility, good manners and common courtesy... tarnishes the entire image of what the bar stands for." 87

Rule 8.2-which prohibits lawyers from making false statements about a judge's integrity-was found violated in a case where the respondent wrote a letter to the judge in his case, which included statements that a decision of the judge was "ridiculous," that the judge had an "underlying incompetence" and was acting "like a robot," and that told the judge "[y]ou simply don't have what is required to decide the kind of issues that you were presented with in this case."

Lastly, a letter sent by a Kansas lawyer to a client was deemed to be "unprofessional, rude, and written to embarrass" another person. ${ }^{89}$ This was found to violate Kansas Rule 8.4 and merited a public censure. ${ }^{90}$

The foregoing cases demonstrate that the Kansas Rules can and should be used to control and regulate unacceptable lawyer conduct in formal proceedings, including depositions, and in their dealings with courts, opposing counsel, and parties. This is a powerful tool to control unprofessional behavior by lawyers, which, when used within constitutional limits, can do much to eliminate rude and discourteous comments. Kansas Rule 4.4(a) also holds out a promise that it can be used to deal with lawyer dilatoriness by providing that "[i]n representing a client, a lawyer shall not use means that have no substantial purpose other than to embarrass, delay, or burden a third person." 91

Unnecessary delay is often cited by lawyers in discussions about what unprofessional behavior is most disturbing. Failure to return telephone calls and messages in a timely manner, failure to schedule necessary conferences in a timely manner, and failure to appear at scheduled meetings thereby necessitating rescheduling at a later date are

87. Id. at 935-36 (citations omitted) (quoting In re Vincenti, 554 A.2d 470, 474 (N.J. 1989) (per curiam); In re Mezzacca, 340 A.2d 658, 659 (N.J. 1975) (per curiam); In re McAlevy, 354 A.2d 289, 291 (N.J. 1976) (per curiam)). A similar, though less colorful, accusatory letter was found to violate Kansas Rule 4.4 in In re Comfort, 159 P.3d 1011, 1021 (Kan. 2007) (per curiam). Another "unprofessional" letter was deemed to be a violation of Kansas Rule 4.4 in In re Pyle, 91 P.3d 1222, 1230-31 (Kan. 2004) (per curiam).

88. In re Amold, 56 P.3d 259, 263-64 (Kan. 2002) (per curiam).

89. In re Bryan, 61 P.3d 641, 644 (Kan. 2003) (per curiam) (quoting the hearing panel's finding of fact).

90. Id. at 658,661 .

91. KAN. Rules of PRof'L Conduct R. 4.4(a) (2007), in KAN. SuP. CT. R. 226. 
all behaviors that could violate Kansas Rule 4.4(a) if sufficiently serious to justify sanction.

\section{CONCLUSION}

The adoption of a professionalism code with prescribed penalties and an associated administrative procedure entails numerous problems. Among these, the administrative burden, the danger of over-regulation, and the encroachment on First Amendment rights all argue against such a code. While concerns about unprofessional behavior at the bar are certainly valid in Kansas, we would argue strongly that the problem does not require a new regulatory scheme and code. Instead, as suggested above, a new focus on professionalism education, combined with a more vigorous use of existing judicial power and an expansive approach to the Kansas Rules of Professional Conduct, should do much to ameliorate the situation. 
VI. APPENDIX

$$
\text { A Lawyer's Creed of Professionalism }{ }^{92}
$$

\section{Preamble}

As a lawyer, I must strive to make our system of justice work fairly and efficiently. In order to carry out that responsibility, not only will I comply with the letter and spirit of the disciplinary standards applicable to all lawyers, but I will also conduct myself in accordance with the following Creed of Professionalism when dealing with my client, opposing parties, their counsel, the courts, and the general public.

\section{A. With respect to my client}

1. I will be loyal and committed to my client's cause, but I will not permit that loyalty and commitment to interfere with my ability to provide my client with objective and independent advice;

2. I will endeavor to achieve my client's lawful objectives in business transactions and in litigation as expeditiously and economically as possible;

3. In appropriate cases, I will counsel my client with respect to mediation, arbitration, and other alternative methods of resolving disputes;

4. I will advise my client against pursuing litigation (or any other course of action) that is without merit and against insisting on tactics which are intended to delay resolution of the matter or to harass or drain the financial resources of the opposing party;

5. I will advise my client that civility and courtesy are not to be equated with weakness;

6. While I must abide by my client's decision concerning the objectives of the representation, I nevertheless will counsel my client that a willingness to initiate or engage in settlement discussions is consistent with zealous and effective representation.

92. Originally printed in Badgerow, supra note 19, at 32-33. Slight grammatical and structural changes have been made to the original for this Essay. The "Lawyers' Pledge of Professionalism" section has been omitted from this Appendix. It can be found at the end of the original printing of the Creed. Id. at 33-34. 


\section{B. With respect to opposing parties and their counsel}

1. I will endeavor to be courteous and civil, both in oral and in written communications;

2. I will not knowingly make statements of fact or of law that are untrue;

3. In litigation proceedings, I will agree to reasonable requests for extensions of time or for waiver of procedural formalities when the legitimate interests of my client will not be adversely affected;

4. I will endeavor to consult with opposing counsel before scheduling depositions and meetings and before rescheduling hearings, and I will cooperate with opposing counsel when scheduling changes are requested;

5. I will refrain from utilizing litigation or any other course of conduct to harass the opposing party;

6. I will refrain from engaging in excessive and abusive discovery, and I will comply with all reasonable discovery requests;

7. I will refrain from utilizing delaying tactics;

8. In depositions and other proceedings, and in negotiations, I will conduct myself with dignity, avoid making groundless objections, and refrain from engaging in acts of rudeness or disrespect;

9. I will not serve motions and pleadings on the other party, or his counsel, at such a time or in such a manner as will unfairly limit the other party's opportunity to respond;

10. In business transactions, I will not quarrel over matters of form or style, but will concentrate on matters of substance and content;

11. I will clearly identify, for other counsel or parties, all changes that I have made in documents submitted to me for review.

\section{With respect to the courts and other tribunals}

1. I will be a vigorous and zealous advocate on behalf of my client, while recognizing, as an officer of the court, that excessive zeal may be detrimental to my client's interests as well as to the proper functioning of our system of justice;

2. Where consistent with my client's interests, I will communicate with opposing counsel in an effort to avoid litigation and to resolve litigation that has actually commenced;

3. I will voluntarily withdraw claims or defenses when it becomes apparent that they do not have merit or are superfluous; 
4. I will refrain from filing frivolous motions;

5. I will make every effort to agree with other counsel, as early as possible, on a voluntary exchange of information and on a plan for discovery;

6. I will attempt to resolve, by agreement, my objections to matters contained in my opponent's pleadings and discovery requests;

7. When scheduled hearings or depositions have to be canceled, I will notify opposing counsel and, if appropriate, the court (or other tribunal) as early as possible;

8. Before dates for hearings or trials are set-or, if that is not feasible, immediately after such dates have been set-I will attempt to verify the availability of key participants and witnesses so that I can promptly notify the court (or other tribunal) and opposing counsel of any likely problem in that regard;

9. In civil matters, I will stipulate to facts as to which there is no genuine dispute;

10. I will endeavor to be punctual in attending court hearings, conferences, and depositions;

11. I will at all times be candid with the court.

D. With respect to the public and to our system of justice

1. I will remember that, in addition to commitment to my client's cause, my responsibilities as a lawyer include a devotion to the public good;

2. I will endeavor to keep myself current in the areas in which I practice and, when necessary, will associate with, or refer my client to, counsel knowledgeable in another field of practice;

3. I will be mindful of the fact that, as a member of a self-regulating profession, it is incumbent on me to report violations by fellow lawyers of any disciplinary rule;

4. I will be mindful of the need to protect the image of the legal profession in the eyes of the public and will be so guided when considering methods and content of advertising;

5. I will be mindful that the law is a learned profession and that among its desirable goals are devotion to public service, improvement of administration of justice, and the contribution of uncompensated time and civic influence on behalf of those persons who cannot afford adequate legal assistance. 